\title{
IMPLEMENTATION OF EXPERIENTIAL LEARNING ACTIVITIES IN ENGLISH PROGRAM AT DPA KINDERGARTEN
}

\author{
Nguyen Danh Nam ${ }^{1 *}$, Nguyen Thi Hong Minh ${ }^{1}$, Nguyen Thi Linh ${ }^{2}$ \\ ${ }^{I} T N U$ - University of Education, ${ }^{2}$ DPA Kindergarten, Thai Nguyen city
}

\section{ABSTRACT}

In Vietnam, there have been some practices in English teaching in recent years that learning should not limit within the class hours but include experiential activities where students gave opportunities to use English in a more realistic and comfortable environment. This experimental research investigates the impact of experiential activities in English teaching on speaking performance of the 6-year-old students at DPA Kindergarten during the school year 2018-2019. The experiential learning activities implemented in DPA Kindergarten in the mentioned time included Drama Show, Ring the Golden Bell (a quasi TV game show), and English Presentation Contest. The study employed a quantitative method. The participants were 68 students aged 6 at DPA Kindergarten, Thai Nguyen city, Vietnam. The results of the students' speaking pre and post-test were processed and analyzed through SPSS version 20. The findings indicated that there is a significant relationship between the implementation of experiential activities in English teaching and the improvement in 6-year-old DPA students' speaking performance. Students who participated in experiential activities in their English study at the kindergarten demonstrated higher scores in the speaking test. In light of the findings, it should advise that experiential activity implemented in English learning for children to enhance their vocal performance.

Keywords: experiential learning; experiential learning activities; speaking performance; teaching English; DPA Kindergarten.

Received: 13/4/2020; Revised: 07/5/2020; Published: 18/5/2020

\section{TỔ CHỨC HOAT ĐÔNG TRẢI NGHIÊM SÁNG TAO TRONG CHƯƠNG TRÌNH TIẾNG ANH TẠI TRƯỜNG MÂMM NON DPA}

\author{
Nguyễn Danh Nam ${ }^{1 *}$, Nguyễn Thị Hồng Minh ${ }^{1}$, Nguyễn Thị Linh ${ }^{2}$ \\ ${ }^{1}$ Truờng Đại học Su phạm - ĐH Thái Nguyên, ${ }^{2}$ Trường Mầm non DPA, thành phố Thái Nguyên
}

\section{TÓM TẮT}

Dạy và học tiếng Anh trong những năm gần đây có nhiều đổi mới. Phương pháp dạy học truyền thống đóng khung việc học ngoại ngữ trong bốn bức tường của lớp học đã và đang được thay thế. Các hoạt động học tập trải nghiệm được đưa vào chương trình tiếng Anh, tạo cơ hội cho người học được sử dụng ngôn ngữ đích trong một môi trường thực và thân thiện. Nghiên cứu thực nghiệm này điều tra ảnh hưởng của hoạt động trải nghiệm sáng tạo trong chương trình tiếng Anh đối với kĩ năng nói của học sinh 6 tuổi trường Mầm non DPA trong năm học 2018-2019. Các hoạt động trải nghiệm sáng tạo được tổ chức ở trường Mầm non DPA trong khuôn khổ nghiên cứu này là: Ngày họi kịch, Rung chuông vàng (hoạt động mô phỏng một chương trình truyền hình), và Thi hùng biện tiếng Anh. Nghiên cứu được dựa trên phương pháp định lượng. Đối tượng nghiên cứu là 68 học sinh 6 tuổi của trường Mầm non DPA, thành phố Thái Nguyên, Việt Nam. Điểm kiểm tra kĩ năng nói trước và sau thực nghiệm của học sinh được xử lý và phân tích bằng phần mềm SPSS 20. Kết quả cho thấy có mối liên hệ quan trọng giữa việc tổ chức các hoạt động trải nghiệm trong việc dạy và học tiếng Anh đối với sự cải thiện trong kĩ năng nói của học sinh 6 tuổi ở trường Mầm non DPA. Những học sinh tham gia các hoạt động trải nghiệm sáng tạo đều có điểm số cao hơn trong bài kiểm tra kĩ năng nói. Từ đó có thể đưa ra khuyến nghị rằng cần tổ chức các hoạt động trải nghiệm sáng tạo trong chương trình tiếng Anh cho học sinh mầm non để nâng cao kĩ năng nói của trẻ.

Từ khóa: học tập trải nghiệm; hoạt động trải nghiệm; kĩ năng nói; dạy tiếng Anh; truờng Mầm non DPA.

Ngày nhận bài: 13/4/2020; Ngày hoùn thiện: 07/5/2020; Ngày đăng: 18/5/2020

\footnotetext{
Corresponding author. Email: danhnam.nguyen@tnue.edu.vn DOI: https://doi.org/10.34238/tnu-jst.2991
} 


\section{Introduction}

Teaching English as a foreign language in Vietnam has received growing interests and attention from individuals to national policies. English officially introduced to the school system since Grade 3, thus, becomes one of the three major subjects with the most prominent time allotment in general school program [1] (The others include Vietnamese Language and Literature, and Mathematics). As a result, many families, especially those with higher living standards in big cities, prepare their children with English learning from a very early age. To meet this significant demand, kindergartens begin to integrate English in their curriculum as an initiative to familiarize young children with foreign language learning in the national school program.

English teaching to young children now in Vietnam is no longer limited to teaching grammar rules and vocabularies. "Learning by doing" or experiential learning in English recently has become more appealing to schools and parents because of its benefits to the development of the language learners.

\section{Literature review}

\subsection{Experiential Learning}

In reality and education theory, learning has always associated with experience; experience is one of the cornerstones of learning. In Kolb's widely accepted model of learning cycle [2], the experience is the initial of a series of steps in the learning cycle whereby new knowledge (learning) created through the combination of grasping and transforming experience.

Experiential learning is then regarded as a holistic educational philosophy based on the ideals that there is a significantly central role of one's life experiences, education, and work in his learning and understanding of new knowledge [3]. Learning involves personal discoveries and experiments, observation, interaction, and exploration of the real world from personal or other classmates' fields of interest.

Mollaei and Rahnama [4] differentiate experiential learning from conventional teaching by listing the following attributes. Experiential learning is learner-centered and individually directed; it focuses on learners' experience and interest, and thus it provokes learners' motivation to learn. Besides, in this learning process, there is minimal facilitation from teachers; as a result, experiential learning develops personal discovery, internal growth, knowledge, skills, and emotions. This philosophy of education, hence, prepares students for the future with flexible and unstructured outcomes and allows variety and diversity as they exist in our real world.

\subsection{Experiential Learning in Language Teaching}

Foreign language education approaches have recently emphasized the significance of the students' contributions to their language learning through initiative-taking and active involvement. Students need to take responsibility for their learning for the development of their autonomy as students and language users [4]. The reason for this is, as suggested by Boud et al. (in [5]), learning builds on and flows from experience and thus can only occur if the experience of the learner is engaged regardless of what external prompts to learning there might be teachers, materials, exciting opportunities.

In the field of second-language acquisition, Knutson [6] believes that the experiential learning allows students to undergo such experiences since it strengthens learners' target language skills through the experience of working together on a specific task, rather than only examining discrete elements of the target language. Moreover, according to Safriani [7], students are encouraged to experience the use of real communication in a setup scene directly, to reflect their feelings and language 
learning experience, and to enable them to link and transfer their experience in the classroom into the real world. As a result, experiential learning offers some potential benefits not only for students' language development, but also for strengthening their independent learning, building motivation, and cultural understanding.

Experiential activities in foreign language learning should ensure that learning takes in a natural, meaningful, and comfortable environment where students are responsible for their learning and thus develop their target language skills as well as life skills. Mollaei and Rahnama [4] recommend a list of experiential learning activities that can apply in language learning. It includes personal journals, diaries; portfolios; reflective personal essays and thought questions; roleplays, drama activities; games and simulations; personal stories and case studies; visualizations and imaginative activities; models, analogies and theory construction; empathy-taking activities; story-telling, sharing with others; discussions and reflection in cooperative groups.

Since experiential learning often characterized by a high level of active involvement in constructing new knowledge, skills, and values, it is regarded by many that it is more closely associated with adult education.

However, children can expose to experiential learning activities to some extent. Children are individual language learners who bring to language learning their curiosity and eagerness to make sense of the world. They tackle the most demanding tasks with enthusiasm and willingness [8]. They love the fun environment, and they want to experiment with things by themselves. They are inquisitive, imaginative, and creative. "Young children do not come to the language classroom empty-handed. They bring with them an already established set of instincts, skills, and characteristics which help them to learn another language" [9].
In this study, Drama Show, Ring the Golden Bell, and English Presentation Contest, which can reflect the characteristics of experiential learning activities for children, are designed and utilized in the English program for 6year-old preschoolers in DPA kindergarten.

\section{Methodology}

This experimental research aimed to investigate whether experiential learning activities are practical for students' English speaking performance. The study employed a quantitative method intended to evaluate the impact of experiential learning activities on students' English speaking skills.

\subsection{Participants}

The participants in this study were 68 students, including 38 females and 30 males at the age of 6 from DPA Kindergarten located in Thai Nguyen City, a northeastern town in Vietnam. These students have been well prepared for formal schooling starting in the upcoming years; hence, generally, they have a basic understanding of literacy and numeration in the native language. Furthermore, most of them have basic knowledge of English and have demonstrated their enthusiasm, eagerness, and strong motivation in learning and joining in experiential learning activities. Nevertheless, there is also a small number of children struggling to learn their mother language and English as well.

\subsection{Data Collection Instruments}

An oral test, employed as a pre and post-test to assess students' speaking performance, used as the research instrument. The test included two tasks: an interview on daily and familiar topics, and a picture description of a similar topic range. An institutional scoring rubric developed to provide a measured quality of performance based on the following criteria: production (language use and pronunciation), reception, non-linguistic competences, and attitude. A five-rating scale 
indicating score 4 'extraordinary,' 3 'excellent,' 2 'acceptable,' 1 'need improvement,' and 0 'poor' utilized to give scores for each criterion.

\subsection{Data Collection Procedure}

The quantitative data collected through the participants' speaking scores recorded from a speaking test that was conducted twice in this study. Firstly, the pre-test utilized to get evidence about the students' current speaking performance. Then the same instrument was employed as the post-test, which was employed to know whether the students' speaking skill improved or not after the implementation of experiential activities (including Drama Show, Ring the Golden Bell and English Presentation Contest conducted within 4 months of the second term in the academic year 2018-2019) in English teaching for the 6-year-olds in the mentioned kindergarten. The students' pre and post-test scores were collected and analyzed through SPSS version 20 to compare the mean score in the two tests and to examine the effectiveness of experiential activities to students' speaking performance.

\section{Findings and discussion}

\subsection{Student's performances reflected in the pre-test}

Table 1. Frequencies of students' pre-test scores

\begin{tabular}{ccc}
\hline Pre-test scores & Frequency & Percent \\
\hline 7.00 & 3 & 4.4 \\
8.00 & 21 & 30.9 \\
9.00 & 31 & 45.6 \\
10.00 & 9 & 13.2 \\
11.00 & 3 & 4.4 \\
12.00 & 1 & 1.5 \\
Total & $\mathbf{6 8}$ & $\mathbf{1 0 0 . 0}$ \\
\hline
\end{tabular}

Table 1 shows the frequencies of students' pre-test scores. The highest percentage of $45.6 \%$ is reflected in the numbers of the test score 9.00 , followed by $30.9 \%$ of the test score 8.00. The maximum scores of 12 occupy $1.5 \%$ reflected in only 1 frequency of students' scores.
Table 2. Descriptive statistics of pre-test on students' performance

\begin{tabular}{lcccc}
\hline & N & Minimum & Maximum & Mean \\
\hline $\begin{array}{l}\text { Pre-test } \\
\text { scores }\end{array}$ & 68 & 7.00 & 12.00 & 8.8676 \\
\hline $\begin{array}{l}\text { Valid N } \\
\text { (listwise) }\end{array}$ & 68 & & & \\
\hline
\end{tabular}

The results of students' performance before participating in experiential activities demonstrated in Table 2. The minimum score of the students' performance was 7 out of 20 (equivalent to $35 \%$ completion of the test) while the maximum was 12 (equivalent to $60 \%$ ). The mean score was 8.8676 .

\subsection{Student's performances reflected in the} post-test

Table 3. Frequencies of students' post-test scores

\begin{tabular}{ccc}
\hline Post-test scores & Frequency & Percent \\
\hline 8.00 & 1 & 1.5 \\
9.00 & 3 & 4.4 \\
10.00 & 12 & 17.6 \\
11.00 & 23 & 33.8 \\
12.00 & 18 & 26.5 \\
13.00 & 8 & 11.8 \\
14.00 & 3 & 4.4 \\
Total & $\mathbf{6 8}$ & $\mathbf{1 0 0 . 0}$ \\
\hline
\end{tabular}

Frequencies of students' post-test scores illustrated in Table 3. The highest percentage of $33.8 \%$ is reflected in the numbers of the test score 11.00 , followed by $26.5 \%$ of the test score 12.00. The maximum scores of 14.00 occupy $4.3 \%$ reflected in only 1 frequency of students' scores - the minimum score of 8.00 accounts for $1.5 \%$, with 1 student receiving such a score.

Table 4. Descriptive statistics of post-test on students' performance

\begin{tabular}{lcccc}
\hline & N & Minimum & Maximum & Mean \\
\hline $\begin{array}{l}\text { Post-test } \\
\text { scores }\end{array}$ & 68 & 8.00 & 14.00 & 11.3235 \\
\hline $\begin{array}{l}\text { Valid N } \\
\text { (listwise) }\end{array}$ & 68 & & & \\
\hline
\end{tabular}

The results of students' performance after the implementation of experiential activities in English teaching for 6-year-olds demonstrated in Table 4. As shown in the table, the minimum score of the students' post-test 
performance was 8 out of 20 (equivalent to $40 \%$ completion of the test) while the maximum was 14 (equivalent to $70 \%$ ). The mean score was 11.3235 .

\subsection{The impact of experiential activities on students' performance}

Table 5. Statistics of pre-test and post-test scores

\begin{tabular}{lccccc}
\hline & & Mean & N & Std. Deviation & Std. Error Mean \\
\hline \multirow{2}{*}{ Pair 1 } & Pretest & 8.8676 & 68 & .96048 & .11648 \\
& Posttest & 11.3235 & 68 & 1.23918 & .15027 \\
\hline
\end{tabular}

As shown in Table 5, the post-test result is higher than the pre-test by 2.4559 (11.3235-8.8676), which means that the students' participation in experiential activities is relatively beneficial to their English speaking performance.

Table 6. Correlations between pre-test and post-test results

\begin{tabular}{lllcl}
\hline & & N & Correlation & Sig. \\
\hline Pair 1 & Pretest \& Posttest & 68 & .488 & .000 \\
\hline
\end{tabular}

The association between pre-test and post-test scores reflected in Table 6 . The correlation coefficient 0.488 with a corresponding p-value of 0.000 indicates a significant relationship. It can indicate that the use of experiential activities in English teaching for 6-year-old schoolers has demonstrated influence on students' English results. It is also noteworthy that high scores in the pre-test go with corresponding high scores in the post-test.

Table 7. Paired differences between pre-test and post-test

\begin{tabular}{|c|c|c|c|c|c|c|c|c|}
\hline & \multicolumn{5}{|c|}{ Paired Differences } & \multirow{3}{*}{$\mathbf{t}$} & \multirow{3}{*}{ df } & \multirow{3}{*}{$\begin{array}{l}\text { Sig. (2- } \\
\text { tailed) }\end{array}$} \\
\hline & \multirow[t]{2}{*}{ Mean } & \multirow[t]{2}{*}{$\begin{array}{c}\text { Std. } \\
\text { Deviation }\end{array}$} & \multirow[t]{2}{*}{$\begin{array}{c}\text { Std. Error } \\
\text { Mean }\end{array}$} & \multicolumn{2}{|c|}{$\begin{array}{l}\text { 95\% Confidence } \\
\text { Interval of the } \\
\text { Difference }\end{array}$} & & & \\
\hline & & & & Lower & Upper & & & \\
\hline Pair 1 & $\begin{array}{l}\text { Pretest - } \\
\text { Posttest }\end{array}$ & -2.45588 & 1.13865 & .13808 & -2.73150 & -2.18027 & -17.786 & 67 \\
\hline
\end{tabular}

The hypothesis test for the difference score 11.00 after the intervention obtains the illustrated in Table 7, where the obtained t- highest percentage (33.8\%), which increases value of 17.786 and the corresponding p- about four times compared to the percentage value of 0.000 at $\mathrm{df}=67$ show significant of that score in the pre-test. In addition, the difference at 0.05 level of significance. This maximum score in the pre-test is 12.00 , but it result means that the introduction of increased 2 more scores in the post-test. What experiential learning activities in the DPA is more, the minimum score of the post-test is kindergarten English program showed 8.00, which is different from the minimum of effectiveness to 6-year-old children's vocal the pre-test (7.00). Based on the data of preperformance.

It clearly showed that there are differences between the frequencies of students' pre-test scores and the frequencies of students' posttest scores. Overall, the post-test result is higher than the pre-test by 2.4559 . Particularly, the number of the test score 9.00 occupies the highest percentage $(45.6 \%)$ in the pre-test, whereas the number of the test test and post-test scores, it demonstrated that 6-year-old DPA students' speaking performance gains a significant difference after the intervention.

As experiential learning activities have not been very conventional in English teaching to young children in Vietnam, for the maximization of its benefits, there should be some considerations for the school and 
teachers who intend to implement these activities in their English program. The following suggestions largely based on Knutson's [6] discussion on overcoming the pitfalls in the application of experiential learning activities in second language learning.

First and foremost, it should advise that the language required in the implementation and performance of the activities be appropriate to students' proficiency levels. If tasks are too linguistically demanding and students expected to function at a much higher level than their proficiency level, it leads to frustration and a tendency of lapse into their mother language. Students seem to enjoy and participate more eagerly in learning activities which are linguistically challenging but remain achievable.

Experiential learning activities involve remarkable cooperation among students, which is an obstacle to supervisors since young children are not fully aware of what collaborative work is. In this case, teachers are supposed to provide a plan of work assigned to every member of the group. Close observations and careful supervision can indeed prove beneficial to promote students' cooperation and communication.

The last but probably the most problematic issue that faces the organizers of experiential learning activities in English program is the issue of assessment. However, let us forget the summative assessment, which tends to be more applicable in more formally academic programs. Formative assessment, including self, peer, and teacher assessment during the process of the learning, provides more useful information for the learning itself. Teacher assessment should aim at supplying instant and spontaneous supports to students' completion of the given tasks as well as better decisions for the adjustment of her teaching and students' learning. Moreover, selfassessment conducted to bring students opportunities to reflect, and self must evaluate their participation and performance. Peer assessment encourages students to observe and think about teammates' work. These are not necessarily for the assessment of the task itself but critical thinking and appreciation of one's own and others' work.

\section{Conclusions}

Based on the previous findings, the study concludes that there is a substantial growth in students' scores of speaking skill after they participate in the three mentioned experiential learning activities in the English program at DPA kindergarten. The number of high scores in students' speaking performance in the posttest surpasses those in the pre-test, whereas such some low scores in the post-test reduce remarkably. Moreover, there exists a significant relationship between taking part in experiential activities in English learning and students' speaking performance. This finding does show that experiential learning activities are beneficial to students' improvement in speaking performance. The research also implies that experiential learning activities should be integrated and implemented in English programs at kindergartens with proper considerations thanks to their positive impacts on the development of target language skills.

\section{REFERENCES}

[1]. The Ministry of Education and Training, Circular No.32/2018/TT-BGDĐT dated December 26, 2018, Hanoi: Ministry of Education and Training, 2018.

[2]. D. Kolb, Experiential learning: Experience as the source of learning and development. New Jersey: Prentice-Hall, 1984.

[3]. A. Kolb and D. Kolb, "The learning way: Meta-cognitive aspects of experiential learning," Simulation Gaming, vol. 40, no. 3, pp. 297-327, 2009.

[4]. F. Mollaei and H. Rahnama, "Experiential education contributing to language learning," International Journal of Humanities and Social Science, vol. 2, no. 21, pp. 268-279, 2012. 
[5]. K. Smith, S. Clubb, E. Lawrence, and M. J. Todd, "The challenges of reflection: Students learning from work placements," Innovations in Education and Teaching International, vol. 44, no. 2, pp. 131-141, 2007.

[6]. S. Knutson, "Experiential learning in second language classrooms," TESL Canada Journal, vol. 20, no. 2, pp. 52-64, 2003.

[7]. A. Safriani, "Experiential learning for language teaching: Adapting Kolb's learning cycle in teaching English as a Foreign Language," 2015. [Online]. Available: http://digilib.uinsby.ac.id/6506/1/27.\%20Expe riential\%20Learning.pdf. [Accessed: Apr. 10, 2020]

[8]. S. Halliwell, Teaching English in the primary classroom. New York: Longman, 1992.

[9]. L. Cameron, Teaching languages to young learners. Cambridge: Cambridge University Press, 2001. 